\title{
THE HEPATIC BLOOD FLOW AND SPLANCHNIC OXYGEN CON- SUMPTION OF MAN-THEIR ESTIMATION FROM UREA PRODUCTION OR BROMSULPHALEIN EXCRETION DURING CATHETERIZATION OF THE HEPATIC VEINS ${ }^{1}$
}

\author{
BY J. D. MYERS \\ (From the Medical Service of Grady Hospital and the Department of Medicine, Emory Uni- \\ versity School of Medicine, Atlanta)
}

(Received for publication June 16, 1947)

The hepatic blood flow was first estimated in normal man by Bradley, Ingelfinger, Bradley and Curry (1). Before applying this bromsulphalein procedure to clinical problems, it seemed advisable not only to confirm their measurements but to estimate hepatic blood flow by a fundamentally different method. The urea method for hepatic blood flow, worked out in the dog by Lipscomb and Crandall (2), has been adapted to normal unanesthetized human subjects. The hepatic venousarterial oxygen difference, total oxygen consumption, and cardiac output have been measured in the same subjects. By multiplying the hepatic vein flow by the hepatic venous-arterial oxygen difference, one obtains an estimate of the splanchnic oxygen consumption. ${ }^{2}$ The oxygen consumption and blood flow of the brain and kidney have been estimated by other investigators. Thus, the measurement of oxygen consumption and blood flow of the splanchnic area allows one to construct a fairly complete picture of the degree of oxygen utilization by and the blood flow through the most important areas of the body.

Urea, among the various metabolites involving the liver, has several attributes which adapt it as a test substance for the estimation of liver blood flow. As far as is known, urea is produced in the human organism only by the liver $(3,4)$ and, once formed, is not converted to other compounds. Urea is very diffusible not only through the vari-

\footnotetext{
1 This work was supported by a grant from the Life Insurance Medical Research Fund.

2 The splanchnic area as used in this paper constitutes the liver plus the area drained by the portal vein. The splanchnic blood flow will be equal to the total hepatic blood flow, but the splanchnic oxygen consumption is greater than that of the liver because the oxygen consumption of all of the portal viscera is included.
}

ous elements of the extracellular fluid but through cell membranes as well. Since the level of urea in arterial blood generally is constant over a period of several hours under conditions of fasting, urea must be lost from the body at the same rate as it is formed, and the total urinary excretion of urea under such conditions approximates hepatic production.

The hepatic blood flow can be calculated, by the "Fick principle," if one knows (a) the concentration of urea in the blood entering the liver (hepatic arterial and portal venous bloods), (b) the concentration of urea in the blood leaving the liver (hepatic venous blood), and (c) the quantitative excretion of urea in the urine during the period when the hepatic blood flow is being measured. Item (c) makes the urea method unadapted to the hepatic blood flow over a short period of time; the flow obtained is really the mean liver blood flow for the period of collection of the urine.

Samples of blood from the hepatic artery and portal vein cannot be obtained in man except by surgical means. Peripheral arterial blood has the same urea content as hepatic arterial blood. Bloods from the portal vein and femoral artery have been found to have identical urea contents in dogs (2), and it is reasonable to assume that this same circumstance holds for man. With this assumption, then, one can utilize the blood of the femoral or brachial artery in place of the true inflow blood of the liver for the determination of urea concentration. Blood from the hepatic vein of man can be obtained directly by the process of venous catheterization as described by Warren and Brannon (5).

\section{METHODS}

Patients, with the one exception noted, had all fasted 6 hours or longer prior to the test. The entire procedure 
was performed in an air conditioned room and excessive urea loss by perspiration was avoided. The urine sample was collected in the standing position by having the patient empty his bladder as completely as possible at the beginning and the end of the procedure. The time interval of collection of the urine averaged about 2 hours.

\section{Catheterization of the hepatic veins}

With the subject in the supine position on the fluoroscopic table, the catheter was inserted into a superficial arm vein under local procaine anesthesia. It was passed under fluoroscopic control into the superior vena cava, through the right atrium and thence into the hepatic veins $(1,5)$. A continuous infusion of 0.9 per cent sodium chloride solution was maintained through the catheter. The subject received on the average 200 to $300 \mathrm{ml}$. of the solution during the entire procedure. In most instances, the catheter entered one of the right hepatic veins. It was introduced so that its tip was located near the center of the right lobe of the liver as visualized by fluoroscopy in the frontal plane. If the catheter was placed farther out along the hepatic veins, it became more difficult to obtain blood samples because the single hole near the tip of the catheter would become occluded intermittently against the wall of the vein. In the larger radicles of the hepatic veins this difficulty is encountered uncommonly. The blood sample is withdrawn gently and necessarily slowly due to the small caliber of the catheter. Under these circumstances, and because of the rapid flow of blood through the hepatic veins, reflux of blood from the inferior vena cava, or right atrium in those cases in which the hepatic veins open directly into that chamber, would appear unlikely if it can occur at all.

Forty-milliliter samples of blood were collected in heparinized syringes from the hepatic vein and femoral artery either simultaneously or within 2 minutes of one another. After a 20- to 30-minute interval, second samples of both hepatic venous and arterial blood were withdrawn. In most instances, a blood sample was taken from the hepatic vein for measurement of oxygen content. The catheter was then partially withdrawn and placed either in the right atrium or preferably in the right ventricle or pulmonary artery. Arterial and mixed venous bloods were taken and a 2 -minute sample of expired air collected in a Douglas bag to be used in determination of the cardiac output.

An attempt was made in each patient to assay the amount of anxiety produced in response to the entire procedure.

\section{Determination of urea in blood}

Because of the small difference in urea concentration between hepatic venous and femoral arterial blood, the determination of the levels of urea in the 2 bloods must be done with maximum accuracy. The method used was a modification of the urease method of Van Slyke and Cullen (6), which utilizes $20 \mathrm{ml}$. of blood in each assay, so that relatively large amounts of urea are being meas- ured. Ten-milliliter samples were found to be too small.

Twenty milliliters of whole heparinized blood were pipetted into a $200-\mathrm{ml}$. volumetric flask and $100 \mathrm{mgm}$. of urease (Squibb double strength) in $2 \mathrm{ml}$. of distilled water were added. No additional buffer was used. After allowing the urease to act for 30 minutes, a tungstate filtrate was made from the blood-urease mixture. A $100-\mathrm{ml}$. aliquot of this filtrate was steam-distilled, using a macroKjeldahl distilling apparatus, after the addition of $100 \mathrm{ml}$. of saturated sodium tetraborate solution. The distillate was caught in an Erlenmeyer flask containing $20 \mathrm{ml}$. of 4 per cent boric acid solution and methyl red as an indicator, and titrated against $0.01 \mathrm{~N}$ sulphuric acid. All determinations were done in duplicate and the results were discarded unless they checked within $0.2 \mathrm{ml}$. of $0.01 \mathrm{~N}$ acid, which is equivalent to $0.06 \mathrm{mgm}$. of urea in the specimen, or $.6 \mathrm{mgm}$. of urea per $100 \mathrm{ml}$. of whole blood. Most duplicate determinations checked within $0.1 \mathrm{ml}$. or less of $0.01 \mathrm{~N}$ acid. The accuracy of this method in detecting small differences in urea concentration in human blood was determined by means of recovery experiments. In each experiment, blood from a normal subject was divided into 4 portions of $20 \mathrm{ml}$. each. A known quantity of urea in aqueous solution, usually $1.0 \mathrm{mgm}$. per $100 \mathrm{ml}$. of blood, was added to 2 samples, and an equal amount of distilled water to the other pair. All 4 were then analyzed for urea content by the procedure outlined above. No experiment was considered satisfactory if the variation between the duplicate determinations exceeded $0.2 \mathrm{ml}$. of $0.01 \mathrm{~N}$ acid. The recoveries in 14 such experiments ranged from 79 to 130 per cent with a mean recovery of $102 \pm 12.4$ per cent. At an urea difference of $1 \mathrm{mgm}$. per $100 \mathrm{ml}$., this equals $0.12 \mathrm{mgm}$. Twice this standard deviation is $0.25 \mathrm{mgm}$. per $100 \mathrm{ml}$. This result would indicate, in the comparison of 2 values (such as an arterial and an hepatic venous urea level) each of which may have a deviation of $\pm 0.25 \mathrm{mgm}$. per $100 \mathrm{ml}$., that a difference of less than $0.5 \mathrm{mgm}$. per $100 \mathrm{ml}$. cannot be considered significant. The accuracy of the method was further investigated by performing 8 analyses on a single specimen of blood. The values obtained for blood urea concentration, in mgm. per $100 \mathrm{ml}$., were: $14.2 ; 13.8 ; 13.9 ; 13.9 ; 13.9 ; 14.2 ; 13.9$; 14.2. The mean of these results is $14.0 \pm 0.17 \mathrm{mgm}$. per $100 \mathrm{ml}$.

\section{Determination of urea in urine}

A volume of urine approximately equal to 1 minute's output was diluted with $20 \mathrm{ml}$. of distilled water and the ammonia removed with 3 grams of permutit. A $10-\mathrm{ml}$. aliquot of this ammonia-free filtrate was treated for 30 minutes with $1 \mathrm{ml}$. of a 5 per cent solution of urease (Squibb, double strength). A tungstate filtrate was then prepared and a large aliquot, usually $50 \mathrm{ml}$., was steamdistilled with sodium tetraborate. The procedure from this point on is the same as for blood.

The oxygen content of the mixed venous and arterial bloods was determined by the method of Van Slyke and Neill (7). The oxygen and carbon dioxide contents of the expired air were measured by the method of Haldane. 


\section{Experimental procedure for bromsulphalein method}

The general conditions of study and the procedure of catheterization were the same as for the urea method.

Bromsulphalein in physiological saline was administered as described by Bradley ét al, using a tunnel clamp (8) and a calibrated Murphy drip. A priming dose of 150 mgm. of bromsulphalein was used. Then an equilibration period of about 30 minutes, with the constant infusion running, is allowed before blood samples are withdrawn. These were then taken simultaneously from the femoral artery and hepatic vein at intervals of approximately 10 minutes.

The bromsulphalein in the serum was determined by means of the Beckman spectrophotometer at a wave length of $580 \mathrm{~m} \mu$. As a rule, $1 \mathrm{ml}$. of serum was diluted with $5 \mathrm{ml}$. of 0.9 per cent sodium chloride solution and $0.1 \mathrm{ml}$. of 10 per cent sodium hydroxide added just before reading. All determinations were made in duplicate with identical values usually being obtained.

Plasma volume determinations were done on every patient whose hepatic blood flow was estimated by the bromsulphalein method. The 10-minute Evans blue (T1824) technique was used. The plasma volume was utilized in calculating the hepatic blood flow in the presence of a rising or falling arterial serum concentration of bromsulphalein (1). No data are included if the bromsulphalein concentration was changing at a rate exceeding $0.0002 \mathrm{mgm}$. per $\mathrm{ml}$. of serum per minute.

\section{RESULTS}

\section{Hepatic blood flow by the urea method}

Fairly complete sets of data were collected on 11 males. Six of these had no disease which is known to involve the liver (epilepsy, low back strain, psychoneurosis, herniated intervertebral disc, brachial neuritis, lacerated thumb). Five were fasting for 6 hours or longer; the sixth was studied 2 hours after his usual lunch. The 5 other patients were well convalescent from acute infection (acute bronchitis, gonococcal arthritis, pneu-

TABLE I

Hepatic blood flow by the urea method-observations on 6 normal and 5 convalescent subjects

\begin{tabular}{|c|c|c|c|c|c|c|c|c|c|c|c|c|c|c|c|c|}
\hline $\begin{array}{l}\text { 造 } \\
\text { है }\end{array}$ & 娄 & 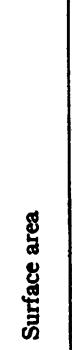 & 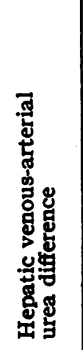 & 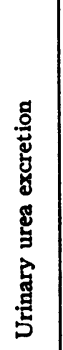 & 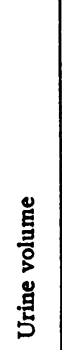 & 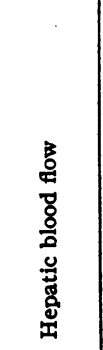 & 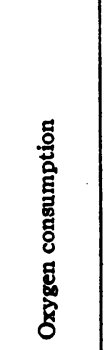 & 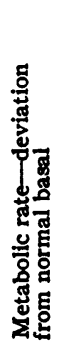 & 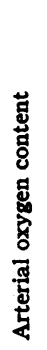 & 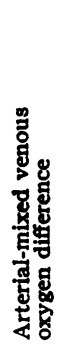 & 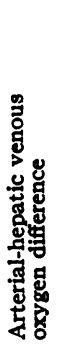 & 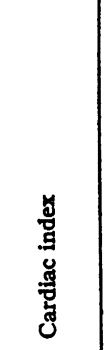 & 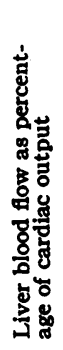 & 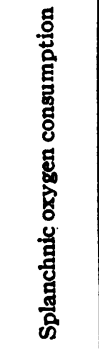 & 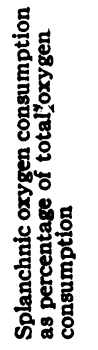 & 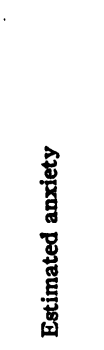 \\
\hline & yrs. & $\begin{array}{c}\text { sq. } \\
\text { meters }\end{array}$ & $\begin{array}{c}\underset{\text { per }}{\operatorname{mgm}} \\
100 \mathrm{ml} .\end{array}$ & $\begin{array}{c}\text { per } \\
\text { min. }\end{array}$ & $\begin{array}{c}m l . \\
\text { per } \\
\text { min. }\end{array}$ & $\begin{array}{l}\text { liters per } \\
\text { min. per } \\
\text { sq. } m \text {. }\end{array}$ & $\begin{array}{c}\text { ml. per } \\
\min . \text { per } \\
\text { sq. } m .\end{array}$ & $\begin{array}{l}\text { per } \\
\text { cent }\end{array}$ & \multicolumn{3}{|c|}{ volumes per cent } & $\begin{array}{l}\text { liters per } \\
\text { min. per } \\
\text { sq. m. }\end{array}$ & $\begin{array}{l}\text { per } \\
\text { cent }\end{array}$ & $\begin{array}{c}\text { ml.per } \\
\text { min.per } \\
\text { sq. } m \text {. }\end{array}$ & per cent & $\begin{array}{c}0=\text { none } \\
\text { to }+4 \\
=\text { marked }\end{array}$ \\
\hline
\end{tabular}

5 Normal, fasting subjects

\begin{tabular}{l|l|l|l|l|l|l|l|l|l|l|l|l|l|l|l|l|l|l}
\hline J. M. & 27 & 1.70 & 0.72 & 12.7 & 4.4 & 1.0 & 174 & +27 & 16.8 & 4.8 & 4.4 & 3.6 & 29 & 45 & 26 & \pm \\
R. L. & 36 & 1.89 & 1.02 & 9.8 & 2.7 & 0.5 & 155 & +23 & 19.0 & 3.2 & 4.1 & 4.8 & 11 & 21 & 14 & \pm \\
C. S. & 34 & 1.74 & 0.93 & 15.2 & 1.5 & 0.9 & & & 18.3 & 4.1 & 4.9 & & & 46 & 2 & 0 \\
H. B. & 25 & 1.75 & 0.93 & 10.1 & 3.4 & 0.6 & 152 & +26 & 19.3 & 3.6 & 5.5 & 4.9 & 13 & 34 & 22 \\
S. W. & 56 & 1.78 & 0.65 & 13.8 & 2.0 & 1.2 & & & & & & & & & & 0 \\
\hline
\end{tabular}

5 Fasting subjects, convalescing from acute infections

\begin{tabular}{l|l|l|l|l|l|l|l|l|l|l|l|l|l|l|l|l|l|}
\hline M. H. & 16 & 1.75 & 0.51 & 13.3 & 5.0 & 1.5 & 216 & +41 & 18.7 & 5.1 & 4.1 & 4.2 & 35 & 61 & 28 & $4+$ \\
E. A. & 21 & 1.78 & 1.14 & 15.3 & 0.5 & 0.8 & 147 & +4 & 15.8 & 3.9 & 3.5 & 3.8 & 20 & 27 & 18 & \pm \\
H. F. & 18 & 1.87 & 0.72 & 13.7 & 0.9 & 1.0 & 160 & +8 & 15.9 & 3.8 & 5.8 & 4.2 & 24 & 59 & 37 & $3+$ \\
G. T. & 22 & 1.85 & 0.81 & 15.0 & 4.9 & 1.0 & & & & & & & & & \\
C. N. & 33 & 1.70 & 0.55 & 14.9 & 1.5 & 1.6 & & & 18.7 & & & & & \\
\hline \multicolumn{3}{c}{ Average values } & 1.0 & 167 & +22 & 17.8 & 4.1 & 4.6 & 4.2 & 22 & 42 & 24 & $4+$ \\
\hline
\end{tabular}

1 Normal subject, non-fasting

\begin{tabular}{l|l|l|l|l|l|l|l|l|l|l|l|l|l|l|l|l}
\hline W. B. & 33 & 1.92 & 1.08 & 24.3 & 2.3 & 1.2 & 171 & +26 & 17.2 & 3.4 & 5.6 & 5.0 & 23 & 53 & 31 & $1+$ \\
\hline
\end{tabular}


mococcal pneumonia-2, and mild typhus fever). The data on both groups of patients are recorded in Table I. There appeared to be no significant differences in the findings on the 5 normal, fasting subjects as compared with the 5 who were convalescent from acute infections. Accordingly, both groups are combined in summarizing results.

The levels of urea in the arterial blood fell between 16.4 and $38.3 \mathrm{mgm}$. per $100 \mathrm{ml}$., and the levels in the hepatic venous blood between 17.3 and $39.4 \mathrm{mgm}$. per $100 \mathrm{ml}$. Hepatic venousfemoral arterial urea differences ranged from 0.51 to $1.08 \mathrm{mgm}$. per $100 \mathrm{ml}$. of blood. The rate of excretion of urea in the urine varied between 9.8 and $15.3 \mathrm{mgm}$. per minute, for an average of 13.4 mgm. per minute. This has been determined on an additional 8 subjects on whom liver blood flows were not measured. In these individuals, the urinary excretion of urea lay between 12.3 and 20.4 mgm. per minute with an average of $16.2 \mathrm{mgm}$. per minute. There was no correlation of urinary excretion of urea with the minute volume of urine in the range encountered $(0.5$ to $5.0 \mathrm{ml}$. per minute). The 1 subject (W. B.) who was studied 2 hours after a meal demonstrated a rate of urea - excretion of $24.3 \mathrm{mgm}$. per minute.

The total hepatic blood flows for the 10 fasting patients range from 1.0 to 2.7 liters per minute. When calculated per square meter of body surface, the range of flows is 0.5 to 1.6 liters per minute with an average flow of 1.0 liter per minute. The hepatic blood flows comprise from 11 to 35 per cent of the total cardiac output, averaging 22 per cent.

Total oxygen consumptions were measured in 6 patients and ranged from 147 to $216 \mathrm{ml}$. per minute per square meter of body surface. These values are in general higher than normal basal oxygen consumption, which is not unexpected in view of the fact that the oxygen consumption was determined near the end of a somewhat trying 2-hour procedure. Every effort was made, however, throughout each study to allay anxiety and keep the subject as comfortable as possible.

The arterial-mixed venous oxygen differences ranged from 3.2 to 5.1 volumes per cent, and the arterial-hepatic venous oxygen differences from 3.5 to 5.8 volumes per cent. In 3 instances the arterial-mixed venous oxygen difference exceeded the arterial-hepatic venous difference, and in 4 subjects the situation was the reverse. It must be remembered that the oxygen contents of mixed venous blood and hepatic venous blood were never determined simultaneously. There was in general a 5- to 10-minute delay involved in moving the catheter from the hepatic vein into the right heart and collecting the mixed venous blood specimen. The cardiac indices (outputs per minute per square meter) varied from 3.6 to 4.9 . The average value for cardiac index was 4.2 liters per minute per square meter, which is about 30 per cent above normal but which is in keeping with the degree of anxiety which was generally encountered. The splanchnic oxygen consumption varied from 21 to $61 \mathrm{ml}$. per minute per square meter in the 7 fasting subjects in whom it was measured. These figures average $42 \mathrm{ml}$. per square meter and equal from 14 to 28 per cent of the total oxygen consumption.

The data for hepatic blood flow, cardiac output, splanchnic oxygen consumption, and total oxygen consumption for the 1 non-fasting subject studied do not vary significantly from the corresponding data for the fasting subjects.

\section{Hepatic blood flow by the bromsulphalein method}

The data for the 9 fasting subjects whose hepatic blood flows were estimated by the bromsulphalein method are recorded in Table II. One female subject (J. E.) is included in this group. Six subjects had conditions thought not to involve the liver (brachial neuritis, psychoneurosis-2, latent bronchial asthma, no disease, and asymptomatic neuro-syphilis). The other 3 subjects were well convalescent from mild, acute infections (pneumococcal pneumonia-2, primary atypical pneumonia-1). Since there is no apparent difference in the results on the normal subjects as compared with the convalescents, the 2 groups of data may be combined.

The range of total hepatic blood flows was from 0.6 to 1.2 liters per minute per square meter, averaging 0.8 liter. This represents from 14 to 26 per cent of the cardiac output, or 19 per cent as an average. Two subjects (H. B. and H. F.) had liver blood flow estimated simultaneously by the urea and bromsulphalein methods with values for H. B. of 0.6 liter per minute per square meter by 
TABLE II

Hepatic blood flow by the bromsulphalein method-observations on 6 normal and 3 convalescent subjects

\begin{tabular}{|c|c|c|c|c|c|c|c|c|c|c|c|c|c|c|c|c|}
\hline 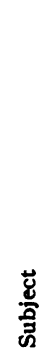 & \& & 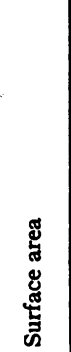 & 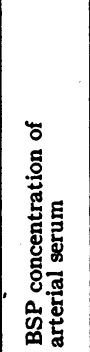 & 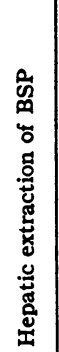 & 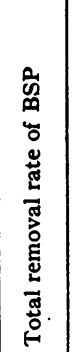 & 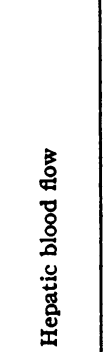 & 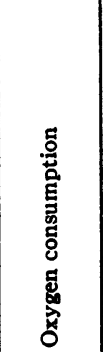 & 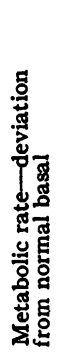 & 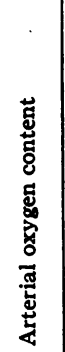 & 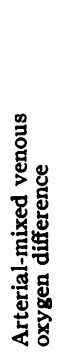 & 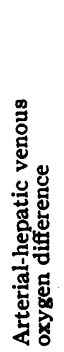 & 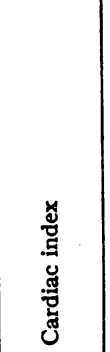 & 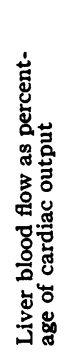 & 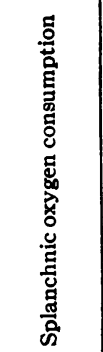 & 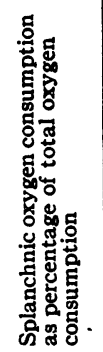 & 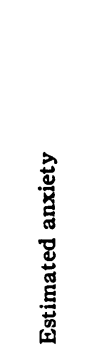 \\
\hline & yrs. & $\begin{array}{c}\text { sq. } \\
\text { melers }\end{array}$ & $\begin{array}{c}\begin{array}{c}m g m . \\
p e r \\
100 \mathrm{ml}\end{array} \\
100\end{array}$ & $\begin{array}{l}\text { per } \\
\text { cent }\end{array}$ & $\begin{array}{c}m g m \\
p e r \\
m i n .\end{array}$ & $\begin{array}{l}\text { liters per } \\
\text { min.per } \\
\text { sq. m. }\end{array}$ & $\begin{array}{c}\text { ml.per } \\
\text { min.per } \\
\text { sq. m. }\end{array}$ & $\begin{array}{c}\text { per } \\
\text { cent }\end{array}$ & \multicolumn{3}{|c|}{ volumes per cent } & $\begin{array}{l}\text { liters per } \\
\text { min. per } \\
\text { sq. m. }\end{array}$ & $\begin{array}{l}\text { per } \\
\text { cent }\end{array}$ & $\begin{array}{l}\text { ml.per } \\
\text { min.per } \\
\text { sq. m. }\end{array}$ & per cent & $\begin{array}{l}0=\text { none } \\
\text { to }+4 \\
=\text { marked }\end{array}$ \\
\hline
\end{tabular}

6 Normal, fasting subjects

\begin{tabular}{l|l|l|l|l|l|l|l|l|l|l|l|l|l|l|l|l}
\hline H. B. & 25 & 1.75 & 1.23 & 54 & 4.76 & 0.7 & 152 & +26 & 19.3 & 3.6 & 5.5 & 4.9 & 14 & 40 & 26 & +3 \\
W. J. B. & 31 & 1.97 & 0.88 & 31 & 6.26 & 1.0 & 138 & +3 & 19.4 & 3.7 & 5.1 & 3.8 & 26 & 56 & 41 & +2 \\
L. M. & 24 & 1.85 & 2.66 & 47 & 7.48 & 0.6 & 156 & +7 & 18.4 & 3.8 & 4.3 & 4.1 & 15 & 26 & 17 & +1 \\
M. A. & 23 & 1.68 & 1.75 & 44 & 7.34 & 0.9 & 178 & +28 & 17.6 & 4.5 & 4.0 & 4.0 & 22 & 37 & 21 & +2 \\
E. F. & 34 & 1.87 & 2.58 & 25 & 7.83 & 1.0 & 172 & +26 & 16.6 & 3.8 & 4.9 & 4.5 & 22 & 49 & 28 & +3 \\
J. W. & 47 & 1.57 & 1.59 & 52 & 5.16 & 0.7 & & & & & & & & & & 0 \\
\hline
\end{tabular}

3 Fasting subjects convalescing from acute infections

\begin{tabular}{l|l|l|l|l|l|l|l|l|l|l|l|l|l|l|l|l|l|l}
\hline H. F. & 18 & 1.87 & 2.34 & 35 & 7.60 & 0.8 & 160 & +8 & 15.9 & 3.8 & 5.8 & 4.2 & 19 & 44 & 28 & $\begin{array}{l}+3 \\
+2 \\
+3\end{array}$ \\
J. E. & 26 & 1.52 & 2.87 & 44 & 7.27 & 0.6 & 130 & +4 & 14.8 & 3.3 & 4.7 & 4.0 & 15 & 28 & 22 & \\
H. H. & 16 & 1.62 & 1.40 & 29 & 4.83 & 1.2 & & & & & & & & & & \\
\hline
\end{tabular}

urea and 0.7 by BSP, and for H. F. of 1.0 by urea and 0.8 by BSP.

Oxygen consumption, which was measured in 7 of the 9 subjects, ranged from 130 to $178 \mathrm{ml}$. per minute per square meter. The corresponding metabolic rates vary from plus 3 to plus 28 per cent of the normal basal metabolic rate, values again in keeping with the amount of anxiety expected and observed. The arterial-mixed venous oxygen differences in 7 subjects ranged from 3.3 to 4.5 volumes per $100 \mathrm{ml}$. of blood, and the arterial-hepatic venous oxygen difference from 4.0 to 5.8 volumes per cent. In 6 of the 7 cases the arterial-hepatic venous difference exceeded the arterial-mixed venous difference. The cardiac indices varied from 3.8 to 4.9 liters per minute per square meter, with an average of 4.2 liters. The splanchnic oxygen consumption was determined in 7 subjects and varied from 26 to $56 \mathrm{ml}$. per minute per square meter with an average of $40 \mathrm{ml}$. These consumptions represent from 17 to 41 per cent of the total oxygen consumption.
In addition to the 11 subjects whose data for hepatic blood flow by the urea method are included in Table I, the urea procedure was carried out in 3 other individuals. The first of these (W. J. B.) had an hepatic venous-arterial urea difference of only $0.4 \mathrm{mgm}$. per $100 \mathrm{ml}$. of blood. This cannot be considered significant in light of the degree of accuracy of the method. A second patient (W. S.) showed the concentration of urea in the femoral arterial blood to be higher, by $0.8 \mathrm{mgm}$. per 100 ml., than the concentration in the hepatic venous blood. Fluoroscopically, the catheter appeared to be in the hepatic veins but the observer could have been mistaken. The third subject (H. H.) also demonstrated lower levels of urea in the hepatic venous blood than in arterial blood. The difference between the first arterial and hepatic venous samples was $0.4 \mathrm{mgm}$. per $100 \mathrm{ml}$.- not a significant difference. The second arterial and hepatic venous samples showed a urea difference of 1.05 mgm. per $100 \mathrm{ml}$. This hepatic venous sample was obtained with considerable difficulty due to 
partial occlusion of the catheter by blood clot. A few minutes later, the catheter was completely thrombosed. This situation may have interfered with the clearing of the catheter of saline before the blood specimen was taken and thus resulted in dilution of the sample with the residual saline in the line. These 3 subjects had urinary urea excretions of $13.9,12.3$, and $19.3 \mathrm{mgm}$. per minute, respectively. Two of these subjects (W. J. B. and $\mathrm{H}$. H.) had simultaneous determinations of liver blood flow by bromsulphalein with values of 1.0 and 1.2 liters per minute per square meter.

Two of the subjects (H. B. and C. S.) who are included in Table I showed, over time periods of 34 and 10 minutes, respectively, corresponding falls in arterial and hepatic venous urea concentrations with maintenance of essentially constant hepatic venous-arterial urea differences. In $\mathrm{H}$. B. the arterial urea level fell from 16.4 to $15.6 \mathrm{mgm}$. per $100 \mathrm{ml}$. while the hepatic venous level changed from 17.3 to $16.5 \mathrm{mgm}$. per $100 \mathrm{ml}$. Thus, the hepatic venous-arterial urea difference remained constant at $0.9 \mathrm{mgm}$. per $100 \mathrm{ml}$. C. S. showed a fall in arterial urea concentration from 27.6 to $27.1 \mathrm{mgm}$. per $100 \mathrm{ml}$; at the same time the hepatic venous concentration fell from 28.5 to 27.8 mgm. per $100 \mathrm{ml}$. The corresponding urea differences are 0.9 and $0.7 \mathrm{mgm}$. per $100 \mathrm{ml}$. It would not seem likely that the corresponding falls in arterial and hepatic venous urea concentrations were due to temporary dilution of the blood volume by the saline infusion through the catheter. In all other subjects the 2 arterial blood urea levels were identical, within the limits of error of the method.

\section{DISCUSSION}

The estimation of hepatic blood flow by the urea method has several disadvantages. The hepatic venous-arterial urea difference is small and requires a meticulous technique for its determination. Even so, small technical errors greatly influence the calculated hepatic blood flow. Because urea is so diffusible throughout the body fluids, i.e., throughout a volume of water equal to approximately $2 / 3$ of the body weight, the retention of a considerable proportion of the urea produced by the liver over a short period of time could occur without a significant rise in urea concentra- tion in the arterial blood. Under such conditions, the urinary excretion of urea would not quantitatively represent urea production by the liver. Hepatic production and renal excretion of urea are probably at or close to equilibrium, however, under the resting and fasting conditions of this study. Kidney function may be affected by such factors as pain and anxiety, which were present in small to moderate degree during the test. The collection of the urine, for determination of urea output, over a period of 2 hours or longer would seem to reduce any effect of pain or anxiety on urea excretion.

The bromsulphalein method gives reproducible results as our average value for hepatic blood flow, 0.8 liter per minute per square meter, agrees closely with that of Bradley et al of 0.9 liter (1). The bromsulphalein method, however, involves several assumptions: (a) that bromsulphalein is removed from the blood stream only by the liver, (b) that the concentration of bromsulphalein in the portal vein is the same as that in peripheral systemic arterial or venous blood, (c) that the percentage of dye extracted by the portion of the liver which is catheterized represents the extraction percentage for the liver as a whole, and (d) that bromsulphalein and/or catheterization of the hepatic veins do not in themselves alter liver blood flow. Those assumptions which are inherent to catheterization of an hepatic vein are involved in the urea method as well.

One must conclude that the urea method is not only technically more difficult but probably considerably less accurate in estimating hepatic blood flow than is the bromsulphalein method. The urea procedure has served a useful purpose in demonstrating that the fundamental assumptions utilized in the dye method are probably correct because similar values for hepatic blood flow can be obtained by an entirely different method. We now feel safer in applying the bromsulphalein method to physiological and clinical problems.

If the values for hepatic blood flow and splanchnic oxygen consumption by both methods are combined, the average hepatic blood flow, 0.9 liter per minute per square meter, is 20 per cent of the cardiac output, and the average splanchnic oxygen consumption of $41 \mathrm{ml}$. per minute per square meter equals 25 per cent of the total oxygen con- 
TABLE III

Comparison of approximate values for blood flow, arterio-venous oxygen difference, and oxygen consumption of brain, kidney and liver of man

\begin{tabular}{|c|c|c|c|c|c|c|c|c|c|c|}
\hline & \multicolumn{2}{|c|}{ Visceral blood flow } & \multicolumn{2}{|c|}{$\begin{array}{l}\text { Arterio-venous } \\
\text { oxygen } \\
\text { difference }\end{array}$} & \multicolumn{2}{|c|}{$\begin{array}{c}\text { Visceral } \\
\text { oxygen } \\
\text { consumption }\end{array}$} & \multicolumn{2}{|c|}{$\begin{array}{l}\text { Visceral blood flow } \\
\text { as percentage of } \\
\text { cardiac output }\end{array}$} & \multicolumn{2}{|c|}{$\begin{array}{l}\text { Visceral oxygen } \\
\text { consumption as } \\
\text { percentage of } \\
\text { total oxygen } \\
\text { consumption }\end{array}$} \\
\hline & Range & Av. & Range & Av. & Range & Av. & Range & Av. & Range & Av. \\
\hline & \multicolumn{2}{|c|}{$\begin{array}{l}\text { ml. per } 100 \text { grams } \\
\text { of tissue per } \\
\text { minute }\end{array}$} & \multicolumn{2}{|c|}{ vol. per cent } & \multicolumn{2}{|c|}{$\begin{array}{l}\text { ml. per } 100 \text { grams } \\
\text { of tissue per } \\
\text { minute }\end{array}$} & & & & \\
\hline $\begin{array}{l}\text { Brain } \\
\text { Kidney } \\
\text { Liver (plus viscera } \\
\quad \text { drained by portal } \\
\quad \text { vein) }\end{array}$ & $\begin{array}{c}59-75 \\
240-510\end{array}$ & $\begin{array}{r}66 \\
330\end{array}$ & $\begin{array}{l}5.7-7.2 \\
1.9-2.5\end{array}$ & $\begin{array}{l}6.5 \\
2.2\end{array}$ & $\begin{array}{l}3.9-4.9 \\
4.1-9.9\end{array}$ & $\begin{array}{l}4.4 \\
8.2\end{array}$ & $18-21$ & $\begin{array}{l}20 \\
20 .\end{array}$ & $20-30$ & $\begin{array}{l}24 \\
12\end{array}$ \\
\hline $\begin{array}{l}\text { (a) Urea method } \\
\text { (b) BSP method }\end{array}$ & $\begin{array}{l}58-185 \\
69-138\end{array}$ & $\begin{array}{r}117 \\
92\end{array}$ & $\begin{array}{l}3.5-5.8 \\
4.0-5.8\end{array}$ & $\begin{array}{l}4.6 \\
4.9\end{array}$ & $\begin{array}{l}2.4-7.0 \\
3.0-6.5\end{array}$ & $\begin{array}{l}5.3 \\
4.6\end{array}$ & $\begin{array}{l}11-35 \\
14-26\end{array}$ & $\begin{array}{l}22 \\
19\end{array}$ & $\begin{array}{l}14-37 \\
17-41\end{array}$ & $\begin{array}{l}24 \\
25\end{array}$ \\
\hline
\end{tabular}

The average body size is assumed to be 1.73 square meters and average visceral weights to be: brain, 1400 grams; kidneys, 170 grams each; and liver, 1500 grams. Data for the brain are from Kety and Schmidt (10), and for the kidney from Warren et al (11), Chasis et al (12), and Bradley and Halperin (13).

sumption. Both the hepatic blood flow and the splanchnic oxygen consumption vary over a wide range from person to person. These variations are not appreciably decreased by relating the values to the surface area of the subject. The splanchnic oxygen consumption was not closely correlated with the total oxygen consumption and only poorly with the hepatic venous-arterial oxygen difference. Both the total oxygen consumption and the cardiac index were somewhat higher than normal in a number of these subjects due, it is thought, to anxiety. It remains to be determined whether more consistent figures can be obtained by studying larger groups of more basal subjects or by studying all subjects after a procedure which will increase the work of the liver and tend to nullify the effects of anxiety. In the study of the cardiac output in the average patient the second technique has been the more useful; the spread in the resting values is considerably reduced by light exercise (9).

The liver is compared, in Table III, with the brain and kidney as to approximate blood flow, arterio-venous oxygen difference and oxygen consumption. The oxygen values recorded for the liver, of course, do not represent oxygen absorbed and utilized only by that viscus, but oxygen metabolized by all the viscera drained by the portal vein as well. The liver and its associated viscera lie between the brain and the kidneys in respect to blood flow per 100 grams of tissue and percentage of oxygen extracted from the arterial blood. The brain has a relatively low blood flow and higher arterio-venous oxygen difference; the kidneys have a very high blood flow but a low $\mathrm{A}-\mathrm{V}$ difference. The liver and brain are about equal in oxygen consumption per 100 grams of tissue; the kidneys have a considerably higher consumption. Each viscus receives around 20 per cent of the resting cardiac output. Together, these viscera account for about 60 per cent of both the cardiac output and the total oxygen consumption of the body at rest.

\section{SUMMARY AND CONCLUSIONS}

1. The hepatic blood flow has been estimated utilizing the Fick principle with urea as the test substance.

2. The hepatic blood flow in 10 normal or convalescent subjects ranged from 0.5 to 1.6 liters per minute per square meter with a mean of 1.0 liter. Hepatic blood flow was estimated on 9 similar subjects by the bromsulphalein method with a range of flows from 0.6 to 1.2 liters per minute per square meter and an average of 0.8 liter. These hepatic blood flows by the 2 methods comprise 22 per cent and 19 per cent, respectively, of the average cardiac outputs.

3. Arterial-hepatic venous oxygen differences, determined at the same time as the hepatic blood flows, provided estimation of the splanchnic oxygen consumption. By the urea method, this ranged from 21 to $61 \mathrm{ml}$. of oxygen consumed per 
minute per square meter with an average of 42 $\mathrm{ml}$. By the bromsulphalein method, the splanchnic oxygen consumption varied between 26 and $56 \mathrm{ml}$. per minute per square meter and averaged $40 \mathrm{ml}$. These averages make up 24 per cent (for the urea method) and 26 per cent (for the bromsulphalein method) of the total oxygen consumption.

4. Because of the small difference in urea concentration between arterial blood and hepatic venous blood, a meticulous technique is required for the urea method, and small technical errors make large variations in the calculated hepatic blood flow. These disadvantages render the urea procedure less suitable for clinical use than is the bromsulphalein method. The fact that these 2 widely different methods give comparable estimates of hepatic blood flow would indicate that the basic assumptions underlying the bromsulphalein method are valid.

\section{ACKNOWLEDGMENT}

The author is indebted to Dr. E. A. Stead, Jr., and to Dr. J. B. Hickam for valuable guidance during this work. Technical assistance was provided by Miss Eloise Cavin, Dr. Shirley H. Cohen, Mrs. Barbara L. Gottlieb, and Miss Mary Norton Maddox.

\section{BIBLIOGRAPHY}

1. Bradley, S. E., Ingelfinger, F. J., Bradley, G. P., and Curry, J. J., Estimation of hepatic blood flow in man. J. Clin. Invest., 1945, 24, 890.

2. Lipscomb, A., and Crandall, L. A., Hepatic blood flow and glucose output in normal unanesthetized dogs. Am. J. Physiol., 1947, 148, 302.
3. Bollman, J. L., Mann, F. C., and Magath, T. B., Studies on the physiology of liver; effect of total removal of the liver on formation of urea. Am. J. Physiol., 1924, 69, 371.

4. Maddock, S., and Svedberg, A., The effect of the total removal of the liver of the monkey. Am. J. Physiol., 1938, 121, 203.

5. Warren, J. V., and Brannon, E. S., A method of obtaining blood samples directly from the hepatic vein in man. Proc. Soc. Exper. Biol. and Med., 1944, 55, 144.

6. Van Slyke, D. D., and Cullen, G. E., The determination of urea by the urease method. J. Biol. Chem., 1916, 24, 117.

7. Van Slyke, D. D., and Neill, J. M., The determination of gases in blood and other solutions by vacuum extraction and manometric measurement. J. Biol. Chem., 1924, 61, 523.

8. Bradley, S. E., A tunnel clamp for use in controlling infusion rates. Science, 1947, 105, 214.

9. Hickam, J. B., and Cargill, W. H., Unpublished observations.

10. Kety, S. S., and Schmidt, C. F., The effects of active and passive hyperventilation on cerebral blood flow, cerebral oxygen consumption, cardiac output, and blood pressure of normal young men. J. Clin. Invest., 1946, 25, 107.

11. Warren, J. V., Brannon, E. S., and Merrill, A. J., A method of obtaining renal venous blood in unanesthetized persons with observations on the extraction of oxygen and sodium para-aminohippurate. Science, 1944, 100, 108.

12. Chasis, H., Redish, J., Goldring, W., Ranges, H. A., and Smith, H. W., The use of sodium paraaminohippurate for the functional evaluation of the human kidney. J. Clin. Invest., 1945, 24, 583.

13. Bradley, S. E., and Halperin, M. E., Renal oxygen consumption and sodium para-aminohippurate extration in normal man during abdominal compression. Federation Proc., 1947, 6, 80. 